\title{
Description and DNA barcoding of Tipula (Pterelachisus) recondita sp. $n$. from the Palaearctic region (Diptera,Tipulidae)
}

\author{
Valentin E. Pilipenko ${ }^{1, \dagger}$, Jukka Salmela ${ }^{2, \ddagger}$, Eero J. Vesterinen ${ }^{3,5}$ \\ I Department of Entomology, Faculty of Biology, Moscow State University, 119899 Moscow, Russia 2 Zoologi- \\ cal Museum, Department of Biology, FI-20014 University of Turku, Finland 3 Section of Ecology, Department \\ of Biology, FI-20014 University of Turku, Finland \\ † urn:lsid:zoobank.org:author:7D4B4321-A9F7-47C4-9133-46C65781B4FE \\ † urn:lsid:zoobank.org:author:D5635C89-AB14-438A-82C8-94E8683A903A \\ § urn:lsid:zoobank.org:author:595D74DB-122A-44BD-B193-0A28DDBD934C \\ Corresponding author: Jukka Salmela (jueesal@utu.fi)
}

Academic editor: V. Blagoderov | Received 15 November 2011 | Accepted 4 May 2012 | Published 8 May 2012

urn:lsid:zoobank.org:pub:651AB2AE-DC5E-4CE5-B748-60410402E5B2

Citation: Pilipenko VE, Salmela J, Vesterinen EJ (2012) Description and DNA barcoding of Tipula (Pterelachisus) recondita sp. n. from the Palaearctic region (Diptera, Tipulidae). ZooKeys 192: 51-65. doi: 10.3897/zookeys.192.2364

\begin{abstract}
Tipula (Pterelachisus) recondita Pilipenko \& Salmela, sp. n. is described. The new species is collected from two localities: Finland, Kittilä (North boreal ecoregion) and Russia, Primorski kray (Zone of temperate broadleaf and mixed forests). Although variation in the structure of male hypopygium between the Finnish and Russian populations is observed, DNA barcode sequences differ only by three nucleotides $(0.2 \%$ $\mathrm{K} 2 \mathrm{P}$ distance), supporting presence of one widespread species. K2P minimum distances between the new species and 17 other species of the subgenus range from 5.3 to $15.8 \%$ (mean $8.8 \%$ ). The new species is forest-dwelling, known from an old-growth herb-rich forest (Finland) and Quercus mongolica forest (Russia). The new species is perhaps closest to $T$. (P.) imitator Alexander and in lesser extent to $T$. (P.) pauli Mannheims; the inner gonostylus of both species are illustrated.
\end{abstract}

\section{Keywords}

Crane flies, Tipulinae, taxonomy, Finland, Russia, COI

Copyright Valentin E. Pilipenko et al. This is an open access article distributed under the terms of the Creative Commons Attribution License 3.0 (CC-BY), which permits unrestricted use, distribution, and reproduction in any medium, provided the original author and source are credited. 


\section{Introduction}

Tipulidae (Diptera, Nematocera), or long-palped crane flies, are medium to large sized true flies. Globally, 4269 tipulid species and subspecies are known, of these 1322 occupying the Palaearctic region (Oosterbroek 2011). In general, northwest European tipulid fauna is rather well known (e.g. Salmela 2010, 2011). The majority of the species have large European or Palaearctic ranges, only a few species are known from Fennoscandia or Russian Karelia alone. On the other hand, certain species have disjunct occurrences in northern Fennoscandia and the East Palaearctic region (viz. Tipula kaisilai Mannheims, T. subexcisa Lundström, T. tchukchi Alexander).

Tipula (Pterelachisus) Rondani is a northern hemisphere subgenus, totaling over 200 species and subspecies (Oosterbroek 2011). Despite taxonomic monographs covering Russia (former USSR, Savchenko 1964) and Europe (Theowald 1980), the Palaearctic fauna of the subgenus includes several elusive species, known from the type locality or female specimens only. Finnish Tipula (Pterelachisus) species were reviewed by Salmela (2009) and those of the Central European territory of Russia were listed by Pilipenko (2009). The subgenus Pterelachisus is closely allied to Lunatipula Edwards and Savtshenkia Alexander, but is diagnosable due to the bare squama, grayish coloration, patterned wings and structure of male hypopygium (Theowald 1980). Savchenko (1964), dealing with the fauna of former USSR, recognized 11 species groups and two mixed groups within Tipula (Geotipula) and T. (Oreomyza). These subgenera were synonymized to Pterelachisus by Alexander (1965) and later Theowald (1980) named 18 species groups from the West Palaearctic region. These species groups are mainly based on differences in the structure of male hypopygium (Theowald 1980), but no cladistic analysis or phylogeny of the species groups was provided by Theowald or authors after him.

DNA barcoding is a molecular-based method used in the identification and delimitation of species, having usually considerable congruence with morphologybased identifications (Ward et al. 2006, Hausmann et al. 2011, Park et al. 2011). Furthermore, barcoding has revealed cryptic diversity within a morphospecies (Smith et al. 2006, Huemer and Hebert 2011) or indicated a presence of one species despite morphological variation within studied specimens (Memon et al. 2006). DNA barcoding has its disadvantages (Meier 2008, Skevington et al. 2007, Taylor and Harris 2012), but it may be used as an additional, and apparently very powerful, method in taxonomy (Schlick-Steiner et al. 2010). Despite the wide use of DNA barcodes in the current taxonomy and biodiversity studies, the method has been only rarely used in taxonomic studies of crane flies (Ujvárosi et al. 2009, Ujvárosi and Bálint 2012).

In the present article we provide a description of Tipula $(P$.$) recondita Pilipenko \&$ Salmela sp. n. collected from Europe (Finland) and Asia (Russian Far East). Both sexes of the new species are richly illustrated. In addition, mtDNA sequences (COI) were used to assess (i) the conspecific status of disjunct Finnish and Russian populations and (ii) genetic divergence between the new species and 17 consubgeneric species. 


\section{Material and methods}

Total DNA of Tipula (P.) recondita Pilipenko \& Salmela sp. n. specimens was extracted using a modified non-destructive salt extraction method (Aljanabi \& Martinez 1997, Gilbert et al. 2007). Whole holotype (JES-20110034) and one paratype (JES20110035) adult specimens and one leg from a paratype (JES-20110036) were placed on $250 \mu \mathrm{l}$ 96-plate wells. Ethanol-stored samples were briefly dried at $60{ }^{\circ} \mathrm{C}$. First 118 $\mu \mathrm{l}$ of sterile salt homogenizing buffer $(0.4 \mathrm{M} \mathrm{NaCl}, 10 \mathrm{mM}$ Tris- $\mathrm{HCl} \mathrm{pH}$ 8.0, $2 \mathrm{Mm}$ EDTA pH 8.0 and $2 \%$ SDS) containing $8 \mu \mathrm{l}$ of $20 \mathrm{mg} / \mathrm{ml}$ proteinase $\mathrm{K}(400 \mu \mathrm{g} / \mathrm{ml} \mathrm{fi-}$ nal concentration) was added into each well. The samples were incubated overnight in the buffer at $55-65^{\circ} \mathrm{C}$. After the incubation, the intact samples were removed from the buffer and placed into $99.5 \%$ ethanol to stop further digestion. Type specimens JES20110034 and JES-20110035 were finally preserved in $70 \%$ ethanol. Then $80 \mu \mathrm{l}$ of 6 $\mathrm{M} \mathrm{NaCl}\left(\mathrm{NaCl}\right.$ saturated $\mathrm{H}_{2} \mathrm{O}, \mathrm{pH}$ 8) was added to each well. Samples were vortexed for $1 \mathrm{~min}$ at maximum speed, and centrifuged for 20 minutes at $4000 \mathrm{rpm}$. Thereafter $100 \mu \mathrm{l}$ of supernatant was transferred to wells on a new plate. An equal volume (100 $\mu \mathrm{l})$ of isopropanol was added to each sample and the plate was briefly vortexed. Then the plate was placed into freezer $\left(-20^{\circ} \mathrm{C}\right)$ for 1 hour. After freezing, the samples were centrifuged for 20 minutes at $4000 \mathrm{rpm}$. The supernatant was discarded and the pellet was washed by adding $150 \mu \mathrm{l}$ of ice-cold $70 \%$ ethanol and centrifuging for $20 \mathrm{~min}$ at $4000 \mathrm{rpm}$. The ethanol was then carefully pipetted out and the pellet was dried for overnight at room temperature. The next day, DNA pellet was dissolved in $50 \mu \mathrm{l}$ of previously warmed ultrapure water.

The DNA barcode region (cythocrome oxidase subunit I) was amplified and sequenced from all specimens using universal primers LCO1490: 5'-GGGTCAACAAATCATAAAGATATTGG-3' and HCO2198: 5'-TAAACTTCAGGGTGACCAAAAAATCA-3' (Folmer et al. 1994). All PCR reactions were performed in a $20 \mu \mathrm{l}$ volume contain-

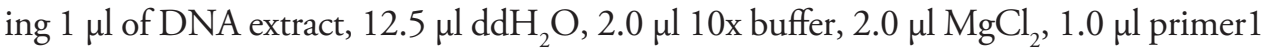
(LCO), $1.0 \mu \mathrm{l}$ Primer 2 (HCO), $0.4 \mu \mathrm{l}$ dNTPs, and $0.1 \mu \mathrm{l}$ AmpliTaq Gold polymerase. The cycling profile was $95^{\circ} \mathrm{C}$ for $5 \mathrm{~min}, 40$ cycles of $94^{\circ} \mathrm{C}$ for $30 \mathrm{sec}, 50^{\circ} \mathrm{C}$ for $30 \mathrm{sec}$, $72^{\circ} \mathrm{C}$ for $1 \mathrm{~min} 30 \mathrm{sec}$ and a final extension period of $72^{\circ} \mathrm{C}$ for $10 \mathrm{~min}$. Sterile water samples were used as controls in each PCR batch. All of the controls were negative. Successful PCR products were purified and sequenced by Macrogen Incorporated (South Korea).

For other species (totaling 17 species and 26 specimens, Table 1) DNA barcodes were obtained at the Canadian Centre for DNA Barcoding. Legs or 2-3 abdominal segments of the specimens were placed in 96\% ethanol in a 96-well lysis microplate and dispatched to the Biodiversity Institute of Ontario where DNA was extracted and sequenced using standard protocols and primers (deWaard et al. 2008). Resultant sequence data were placed into a project (HOLPT) on BOLD (http://www.boldsystems.org, Ratnasingham and Hebert 2007). These sequence records are now publically available on both BOLD and on GenBank.

In order to assess the COI divergence between the new species and 17 Holarctic Tipula (Pterelachisus) species, we calculated Kimura two-parameter (K2P) (Kimura 
Table I. Tipula (Pterelachisus) specimens used in DNA barcoding (COI). Species and associated BOLD Sample ID are according to HOLPT project, available in http://www.boldsystems.org/. Co-ordinates are given in WGS84 decimal format.

\begin{tabular}{|c|c|c|c|c|c|}
\hline Sample ID, species & Year & Country & Locality & $\mathbf{N}$ & $\mathbf{E}$ \\
\hline JES-20110456|Tipula_cinereocincta & 2005 & Finland & Heinävesi & 62.419 & 28.596 \\
\hline JES-20120024|Tipula_cinereocincta & 2007 & Finland & Savonranta & 62.251 & 28.877 \\
\hline JES-20120065|Tipula_angulata & 2006 & Canada & Ontario & 45.483 & -76.081 \\
\hline JES-20120064|Tipula_entomophthorae & 2003 & Canada & Manitoba & 54.9 & -101.43 \\
\hline JES-20120004|Tipula_jutlandica & 2008 & Finland & Parikkala & 61.565 & 29.559 \\
\hline JES-20110501|Tipula_laetibasis & 2002 & Finland & Tuupovaara & 62.442 & 30.606 \\
\hline JES-20110497|Tipula_luridorostris & 2006 & Finland & Taivalkoski & 65.785 & 28.321 \\
\hline JES-20120011|Tipula_mats._pseudohortensis & 2007 & Finland & Inkoo & 60.018 & 23.822 \\
\hline JES-20110475|Tipula_mats._pseudohortensis & 2007 & Finland & Siuntio & 60.213 & 24.135 \\
\hline JES-20110092|Tipula_mutila & 2009 & Finland & Enontekiö & 68.639 & 22.552 \\
\hline JES-20110204|Tipula_mutila & 2008 & Finland & Kiuruves & 63.52 & 26.69 \\
\hline JES-20120095|Tipula_mutila & 2007 & Finland & Kittilä & 68.33 & 24.64 \\
\hline JES-20120014|Tipula_octomaculata & 2008 & Finland & Lieksa & 63.217 & 30.218 \\
\hline JES-20120031|Tipula_octomaculata & 2006 & & Taivalkoski & 65.693 & 28.32 \\
\hline JES-20110494|Tipula_pauli & & & Primorski kray & 47.94 & \\
\hline JES-20110495|Tipula_pauli & 1995 & Russia & Moscow region & 56.02 & 37.11 \\
\hline JES-20110502|Tipula_pseudovariipennis & 2006 & Latvia & Tukums & 56.998 & 23.003 \\
\hline JES-20110035|Tipula_recondita_sp._n & 2009 & Finland & Kittilä & 67.634 & 25.416 \\
\hline JES-20110034|Tipula_recondita_sp._n & 2009 & Finland & Kittilä & 67.634 & 25.416 \\
\hline JES-20110036|Tipula_recondita_sp._n & 2006 & & Primorski kray & 43.125 & 131.4 \\
\hline JES-20120038|Tipula_st & & Finland & Kitti & 67.634 & \\
\hline JES-20110408|Tipula_submarmorata & 2009 & Finland & Jyväskylä & 62.236 & 25.679 \\
\hline JES-20120041|Tipula_truncorum & 2010 & Finland & Enontekiö & 69.183 & 21.521 \\
\hline JES-20110345|Tipula_varipennis & 2007 & Finland & Ranua & 66.017 & 26.852 \\
\hline JES-20120032|Tipula_varipennis & 2005 & Finland & Jyväskylä & 62.213 & 25.793 \\
\hline JES-20110401|Tipula_varipennis & 2009 & Finland & Jyväskylä & 62.236 & 25.679 \\
\hline JES-20110222|Tipula_wahlgreni & 2008 & Finland & Kiuruvesi & 63.52 & 26.69 \\
\hline JES-20110450|Tipula_winthemi & 2009 & Finland & Lammi & 61.091 & 25.002 \\
\hline JES-20120026|Tipula_winthemi & 2008 & Finland & Virolahti & 60.465 & 27.426 \\
\hline
\end{tabular}

1980) distances between all sequenced specimens. Based on K2P distances we also produced Neighbor-Joining (NJ) tree to visualize similarity of the Pterelachisus species. We also inferred relatedness of the species with character based Maximum Likelihood (ML) method (GTR + gamma as evolutionary model, 1000 Bootstrapping replicates). However, because the NJ and ML trees were practically identical, only ML tree is presented (Fig. 1). K2P distances, NJ and ML were produced by using MEGA5 program (Tamura et al. 2011). Because one gene is far too little for reasonable phylogenetic analysis (Gatesy et al. 2007), the ML tree presented here do not reliably illustrate evolutionary relationships among the sequenced taxa.

The morphological terminology used here mainly follows Alexander and Byers (1981). Terminology of some special parts of male genitalia was taken from Frommer (1963). If not otherwise stated, measurements are given in $\mu \mathrm{m}$. The following acro- 


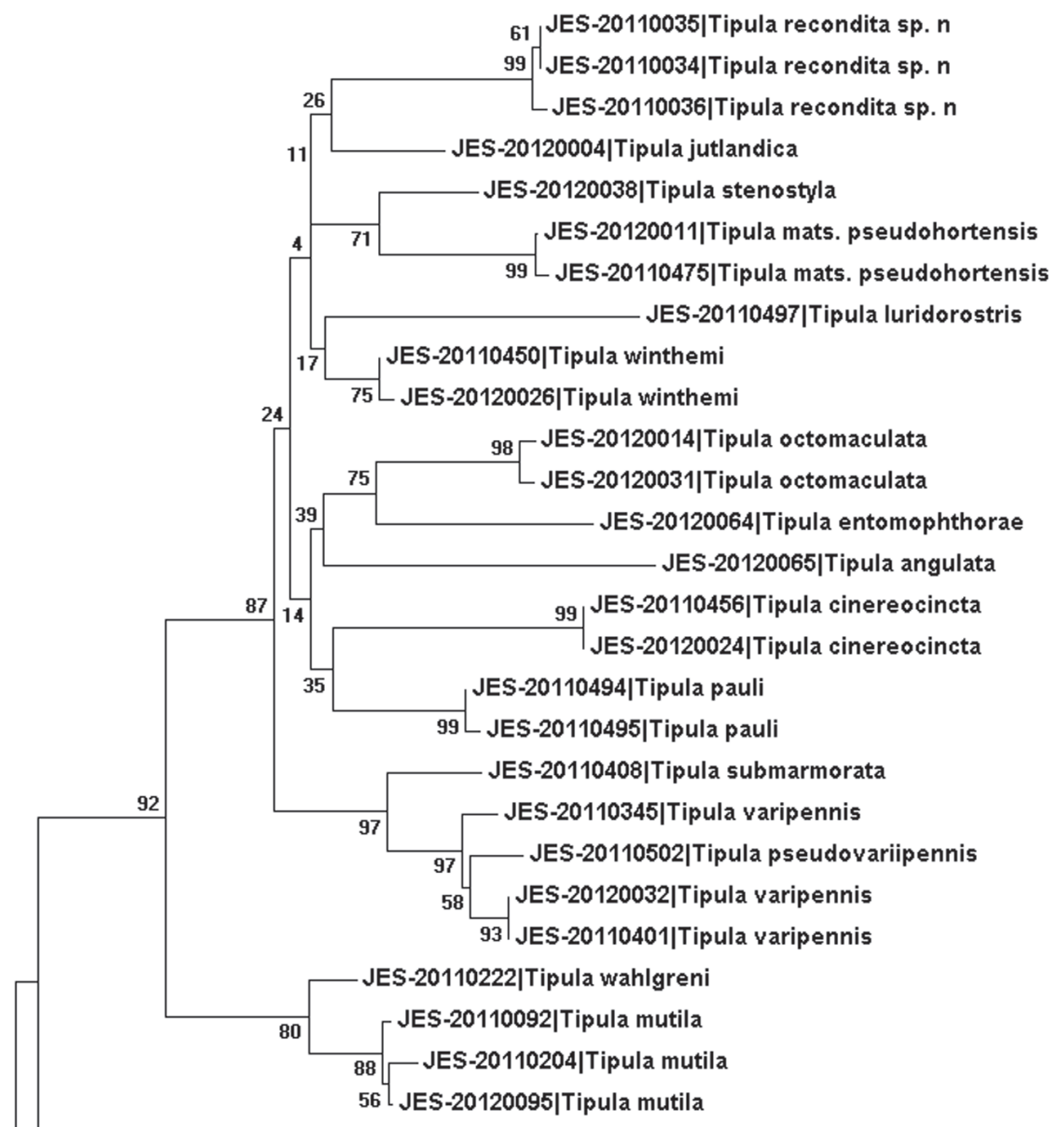

JES-20120041|Tipula truncorum

JES-20110501|Tipula laetibasis

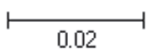

Figure I. Maximum Likelihood tree based on COI sequences (mtDNA) of 17 Tipula (Pterelachisus) species. Numerical values denote to Bootstrap values after 1000 replications. In the tree Bootstrap value 26 refers to the clade including T. recondita sp. $\mathrm{n}$. and T. jutlandica and value 11 refers to the clade including T. recondita sp. n., T. jutlandica, T. stenostyla and T. matsumuriana psedohortensis. Scale bar: nucleotide substitutions per site.

nyms for museums and collections are used in the text: ZMKU - Zoological Museum of National Museum of Natural History, National Academy of Science of Ukraine, Kiev, Ukraine; NCBN - Netherlands Centre for Biodiversity Naturalis, Leiden, the 
Netherlands; ZMUM - Zoological Museum, Moscow State University, Moscow, Russia; ZMUT - Zoological Museum, University of Turku, Turku, Finland; ZISP - Zoological Institute Russian Academy of Sciences, St. Petersburg, Russia; VPM Private collection of Valentin Pilipenko, Moscow, Russia.

Specimens were studied with a Zoom Stereo Microscope. Photographs were taken with a Canon PowerShot A640 camera and processed using Combine ZP software. All drawings were prepared from photographs.

[Comparative morphological material examined. Tipula (P.) imitator Alexander: Russia, Shikotan Island, Kray Sveta cape, 25.VII.1965, V. Ermolenko, 1 male (ZMKU); Russia, Iturup Island (Kuril Is), Kurilsk env., 5.VII.1963; Krilov \& Krivolutskaya, 1 male (ZISP). Tipula (P.) pauli Mannheims: Russia, Moscow region, Chashnikovo, 29.V.1995, V. Pilipenko, 1 male (VPM).]

\section{Taxonomy}

Tipula (Pterelachisus) recondita Pilipenko \& Salmela, sp. n. urn:lsid:zoobank.org:act:CFBAD0A0-AC21-4067-88E4-C15BCA35CC56 http://species-id.net/wiki/Tipula_recondita

Material examined. Holotype: Male, in alcohol (NCBN). "Finland, Lkoc: Kittilä, Iso Mustavaara, old-growth herb-rich forest, $67.6340^{\circ} \mathrm{N}, 25.4160^{\circ} \mathrm{E}, 30 . \mathrm{V} .-1$.VII. 2009, J. Salmela leg." (white label, printed) "Tipula (Pterelachisus) recondita sp. n./ Pilipenko \& Salmela 2011/ HOLOTYPE" (white label, printed) "BOLD sample ID JES20110034" (white label, printed). Both wings are detached. Only one leg is present, other legs are missing. Tip of abdomen is detached and, including separate sperm pump, preserved in a microvial. This microvial is in the same tube as are wings and rest of the specimen. DNA barcode (524 bp) of holotype (coded JES-20110034|FINTI03411|Tipula recondita):

ATGCTTTTATTATAATTTTTTTTATAGTTATACCTATTATAATTGGAGGATTTGGAAATTGATTAGTACCTTTAATATTAGGTGCCCCTGATATAGCCTTTCCTCGAATAAATAATATAAGTTTTTGAATATTACCTCCTTCACTTACTCTTTTATTAGCTAGTAGTATAGTCGAAAACGGTGCGGGGACTGGATGAACCGTTTATCCCCCACTCTCATCTAGAATTGCCCATACAGGAGCTTCAGTTGATTTAGCCATTTTTTCTCTTCATTTAGCTGGAATTTCTTCAATTTTAGGAGCAGTAAATTTTATTACTACAGTAATTAATATACGATCAAGAGGAATTACTTTAGACCGAATACCTTTATTTGTTTGATCGGTAGTAATTACTGCAGTATTATTACTACTCTCTTTACCTGTATTAGCGGGAGCTATTACTATACTTTTAACTGATCGAAATTTAAATACATCATTTTTTGATCCTGCAGGAGGTGGAGATCCAATTCTTTACCAACATTTATTT

Paratypes. Finland, Lkoc: Kittilä, Iso Mustavaara Nature reserve, herb-rich oldgrowth forest, $67.6340^{\circ} \mathrm{N}, 25.4160^{\circ} \mathrm{E}, 30$. V.-1.VII. 2009, Malaise trap, J. Salmela leg., 
2 males (ZMUT, in alcohol [BOLD sample ID JES-20110035] and a pinned specimen). DNA barcode (524 bp) of paratype (JES-20110035|FINTI035-11) is identical to the holotype sequence. Russia, Far East, Primorski kray, Kedrovaya Pad', oak forest (Quercus mongolica), $43.1301^{\circ} \mathrm{N}, 131.5041^{\circ} \mathrm{E}, 7 . \mathrm{VII}$. 2006 V. Pilipenko leg., 3 males and 3 females, deposited in ZSIP (BOLD sample ID JES-20110036), ZMUM, VPM. DNA barcode (524 bp) of paratype male (JES-20110036|FINTI036-11) differs from holotype at three positions $(212=\mathrm{C}, 473=\mathrm{T}$, and $515=\mathrm{G})$. In other words, intraspecific K2P distance between Finnish and Russian specimens was $0.2 \%$.

Diagnosis. Rather small yellowish brown Tipula species (body length: $11 \mathrm{~mm}$ male, $12.3 \mathrm{~mm}$ female; wing length $11-12.6 \mathrm{~mm}$ male, $12.5-13.5 \mathrm{~mm}$ female). Scape, pedicel and base of $1^{\text {st }}$ flagellomere yellowish, other flagellomeres brown. Caudal margin of male $9^{\text {th }}$ tergite with a median notch, bearing no tooth or other elevated structures. Outer gonostylus narrow, about as long as inner gonostylus, slightly bent subbasally. Lower beak of inner gonostylus apically rounded, black. Outer basal lobe of inner gonostylus with 3-4 stout black spines.

Description. Male. Head gray pruinose, sparsely covered with dark hairs. Base of rostrum gray pruinose, otherwise dark brown, shining. Nasus distinct, tip with light bristles (Fig. 2a). Palpi brownish. Lengths of palpal segments ( $n=2)$ : p1 128-147, p2 307-309, p3 317-365, p4 309-333 and p5 1207-1359. Scape, pedicel and base of $1^{\text {st }}$ flagellomere yellowish, other flagellomeres brown. Scape cylindrical (length 442-466, width 119-120, n=2). Pedicel globular (length 132-134, width 134-135, n=2). Flagellar segments cylindrical, covered with silvery, erect and thick pubescence. Verticils black, shorter than respective segments (Fig. 2a). Lengths of flagellomeres $(n=2)$ : f1 371-398, f2 312-314, f3 298-316, f4 289-326, f5 297-324, f6 296-325, f7 291, f8 270-289, f9 257-261, f10 227-230 and f11 100. Thorax. General coloration dark brown, with gray pruinosity (Fig. 2b). Pronotum with light hairs. Prescutum with four longitudinal brown bands; lateral bands short, median bands distinctly separated. Anepisternum, katepisternum and anepimeron with dense, gray pruinosity. Scutum, scutellum, laterotergite and mediotergite unicolorous, dark brown. Coxae brown, with light hairs. Trochanters yellowish, with light hairs. Proximal part (ca. two thirds) of femora yellowish, turning dark brown toward tips. Tibiae and tarsi dark brown, spur formula 1:2:2. Tarsal claws smooth. Legs covered with dark brown - black bristles. Stem of halter yellowish, knobs infuscated. Wings with marmorate pattern, length $(\mathrm{n}=5) 11.9$ $\mathrm{mm}(11-12.6 \mathrm{~mm})$, venation as in Fig. $2 \mathrm{c} . \mathrm{R}_{1+2}$ is variable, reach or not reach Costa. Wing cells $c$ and sc yellowish, other cells brown tinged (see Figs. 2b, 2c). Pterostigma distinct. Abdomen yellowish brown, with a narrow dorsal stripe (Fig. 2b). Hypopygium (Fig. 3a) dark brown. Caudal margin of $9^{\text {th }}$ tergite with a median notch, bearing no tooth or other elevated structures (Figs. 3g-h). Caudal margin of $9^{\text {th }}$ tergite oblique (Finnish specimens) or almost horizontal, truncated (Russian specimens) (Figs. 3g-h). Outer gonostylus narrow, about as long as inner gonostylus, slightly bent sub-basally (Figs. 3b, d). Lower beak of inner gonostylus apically rounded, black. Beak of inner gonostylus rather narrow and elongated in lateral view (Figs. 3b, d), tip roundish and proximal margin oblique, notched in posterior view (Fig. 3c). Outer basal lobe of inner 

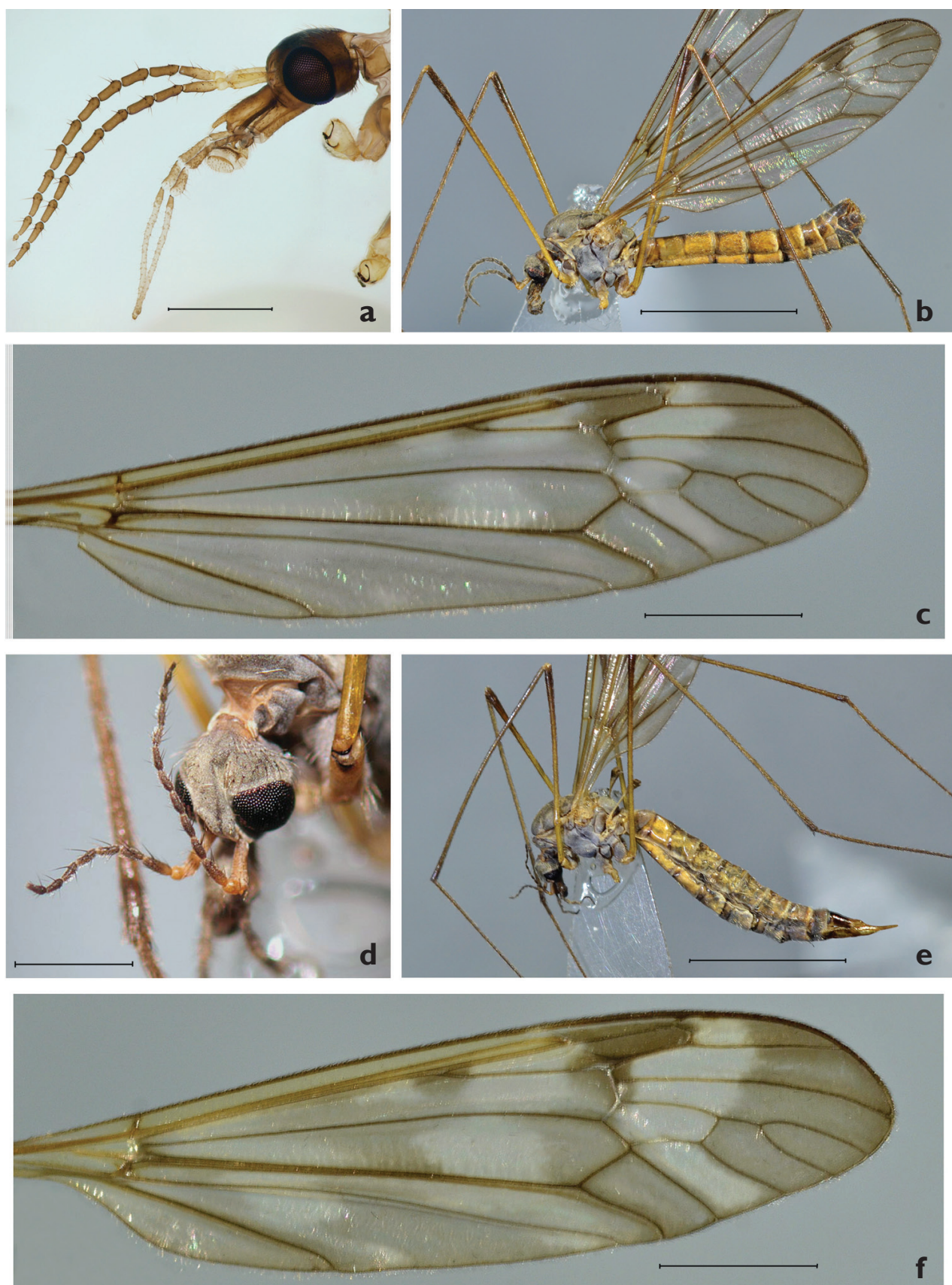

Figure 2. Tipula (Pterelachisus) recondita Pilipenko \& Salmela, sp. n. a Holotype male, head, lateral view (Finland) b paratype male, habitus, lateral view (Russia) c paratype male, wing (Russia) $\mathbf{d}$ paratype female, head, dorso-lateral view (Russia) e paratype female, habitus, lateral view (Russia) f paratype female, wing (Russia). Scale bars: a, d $1 \mathrm{~mm}$; c, f $2.5 \mathrm{~mm}$; b, e $5 \mathrm{~mm}$. 

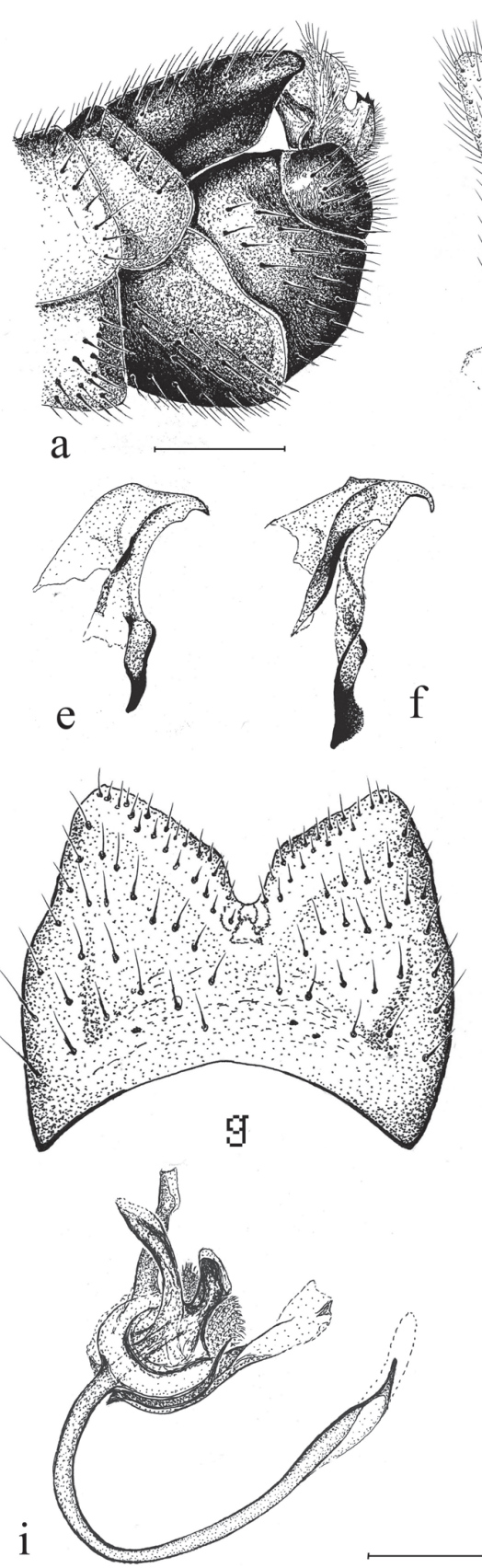

$\mathrm{f}$
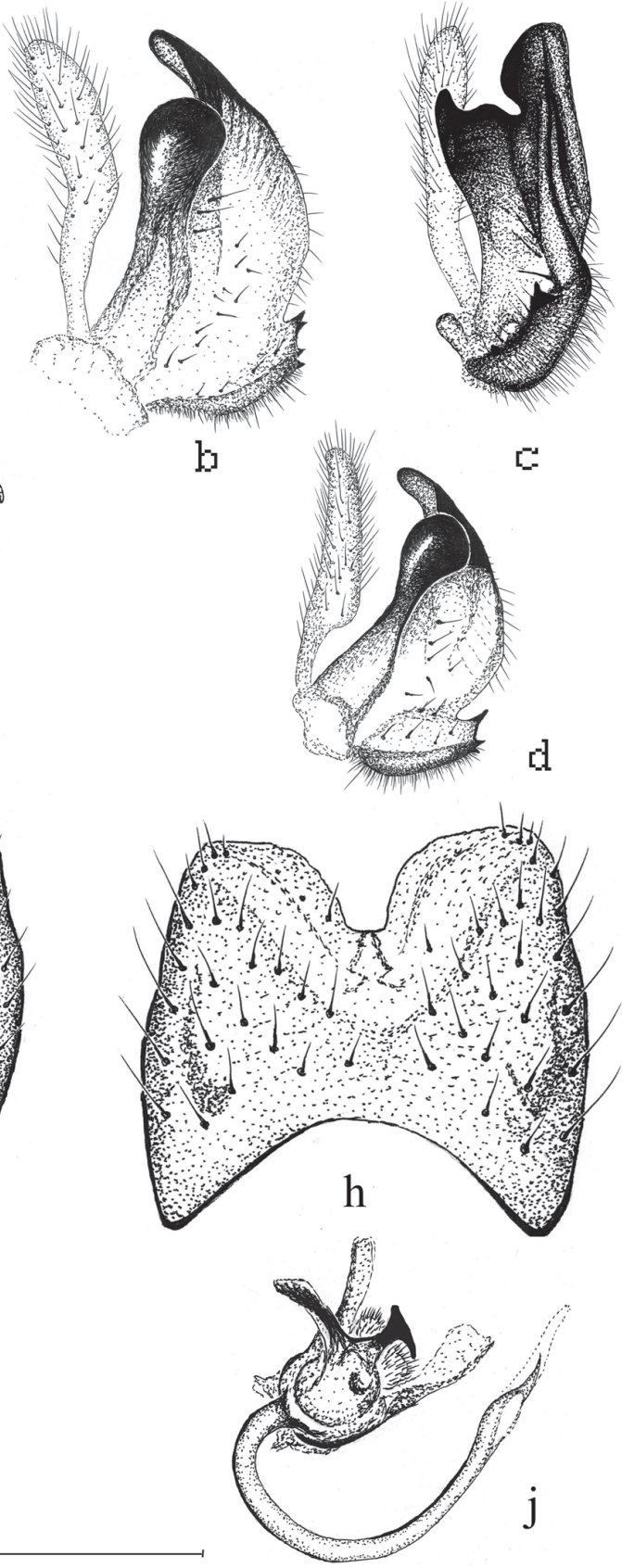

Figure 3. Tipula (Pterelachisus) recondita Pilipenko \& Salmela, sp. n., paratype males a hypopygium, lateral view (Russia) b outer and inner gonostylus, lateral view (Finland) c outer and inner gonostylus, posterior view (Finland) $\mathbf{d}$ outer and inner gonostylus, lateral view (Russia) e aedeagal guide, lateral view (Finland) $\mathbf{f}$ aedeagal guide, lateral view (Russia) $\mathbf{g} 9^{\text {th }}$ tergite, dorsal view (Finland) $\mathbf{h} 9^{\text {th }}$ tergite, dorsal view (Russia) $\mathbf{i}$ sperm pump and aedeagus, ventro-lateral view (Finland) $\mathbf{j}$ sperm pump and aedeagus, ventrolateral view (Russia). Scale bars: $0.5 \mathrm{~mm}$. 
gonostylus with 3-4 stout black spines. Aedeagal guide as in Figs. 3e-f. Sperm pump hairy between posterior immovable apodemes, apex of aedeagus pointed (Figs. $3 \mathrm{i}-\mathrm{j}$ ).

Female. Wing length $(\mathrm{n}=3) 12.8 \mathrm{~mm}(12.5-13.5 \mathrm{~mm})$, body length $(\mathrm{n}=3) 12.3$ $\mathrm{mm}(12-13 \mathrm{~mm})$. Generally similar to male (Fig. 2e). Antenna short $(2.4 \mathrm{~mm})$, not extending to wing base (Fig. $2 \mathrm{~d}$ ). The wing's marmorate pattern more intensive than in male (Fig. 2f). Ovipositor (Figs. 4a, b) elongate, similar to that of most other tipulines; $8^{\text {th }}$ tergite dark brown, 9th tergite narrow dull dark brown, $10^{\text {th }}$ tergite shining chestnut brown. $8^{\text {th }}$ sternite dull dark brown anteriorly, grading to shining yellow posteriorly. Cerci narrow, yellow, slightly longer than $10^{\text {th }}$ tergite. Hypogynial valves yellow, reaching mid-length of cerci, relatively wide, gradually narrowing (Fig. 4c).

Etymology. The species epithet is from reconditus (Latin, adjective) meaning hidden, concealed. This word refers to the rarity and apparent low detectability of the new species, so far known only from two sites in the Palaearctic region.

Distribution and ecology. Tipula $(P$.$) recondita Pilipenko \& Salmela, sp. n. is$ known from North Europe (Finland) and Asia, Russian Far East. The Finnish collecting site in Kittilä, Iso Mustavaara, is a state-owned Nature Reserve (Lehtojensuojelualue), included in the Natura2000 network of conservation areas. It is part of the biogeographical province of Lkoc (Lapponia kemensis pars occidentalis) and lies in the North boreal vegetation zone. The collecting site is an old-growth mixed forest, dominated by birch (Betula pubescens), goat willow (Salix caprea) and Norway spruce (Picea abies), with scattered aspen (Populus tremula) trees. Lower vegetation is characterized by herbs and shrubs such as Calypso bulbosa, Daphne mezereum, Actaea erythrocarpa, Ribes spicatum, Filipendula ulmaria and Geranium sylvaticum. Decaying trees, especially goat willow and birch, are abundant in the site. The Russian collecting site is located in the Kedrovaya Pad' Nature Reserve, within the temperate broadleaf and mixed forest zone, in an oak forest (Quercus mongolica) growing on limestone outcrops on the southern slope of a mountain range. Lower vegetation is characterized by Lespedeza bicolor, Spodiopogon sibirieus, Astra ageratoides, Carex siderosticta, Artemisia keiskeana, Lathyrus davidii and Calamagrostis brachytricha.

Discussion. Tipula (P.) recondita Pilipenko \& Salmela, sp. n. is rather easily distinguished from other Holarctic Tipula (Pterelachisus) species. The new species is distinctive in characters of the male hypopygium, especially that of the $9^{\text {th }}$ tergite. There are several Tipula (Pterelachsus) species with a U-shaped median notch or an emargination in the caudal margin of the tergite, but usually having a tooth or other elevated structures at the mid-point (e.g. T. (P.) angulata Loew [Alexander 1919, p. 984, Salmela \& Autio 2007, p. 55], T. (P.) varipennis Meigen [Savchenko 1964, p. 56], T. (P.) imitator Alexander [Alexander 1953, Plate 1], T. (P.) resupina Alexander [Alexander 1935, Plate 2]); the new species is peculiar having no such structures in the $9^{\text {th }}$ tergite.

Morphologically the new species is perhaps the closest to two Palaearctic species, namely $T$. (P.) imitator and $T$. (P.) pauli. The former species has a median notch in $9^{\text {th }}$ tergite, but also a distinct tooth at the midpoint (Fig. 4g); the outer basal lobe of inner gonostylus bears one conspicuous black spine, not 3-4 smaller ones (Fig. 4e). For other differences, see Figures $4 \mathrm{f}, \mathrm{h}$, i. Tipula pauli also has a median notch in $9^{\text {th }}$ tergite 

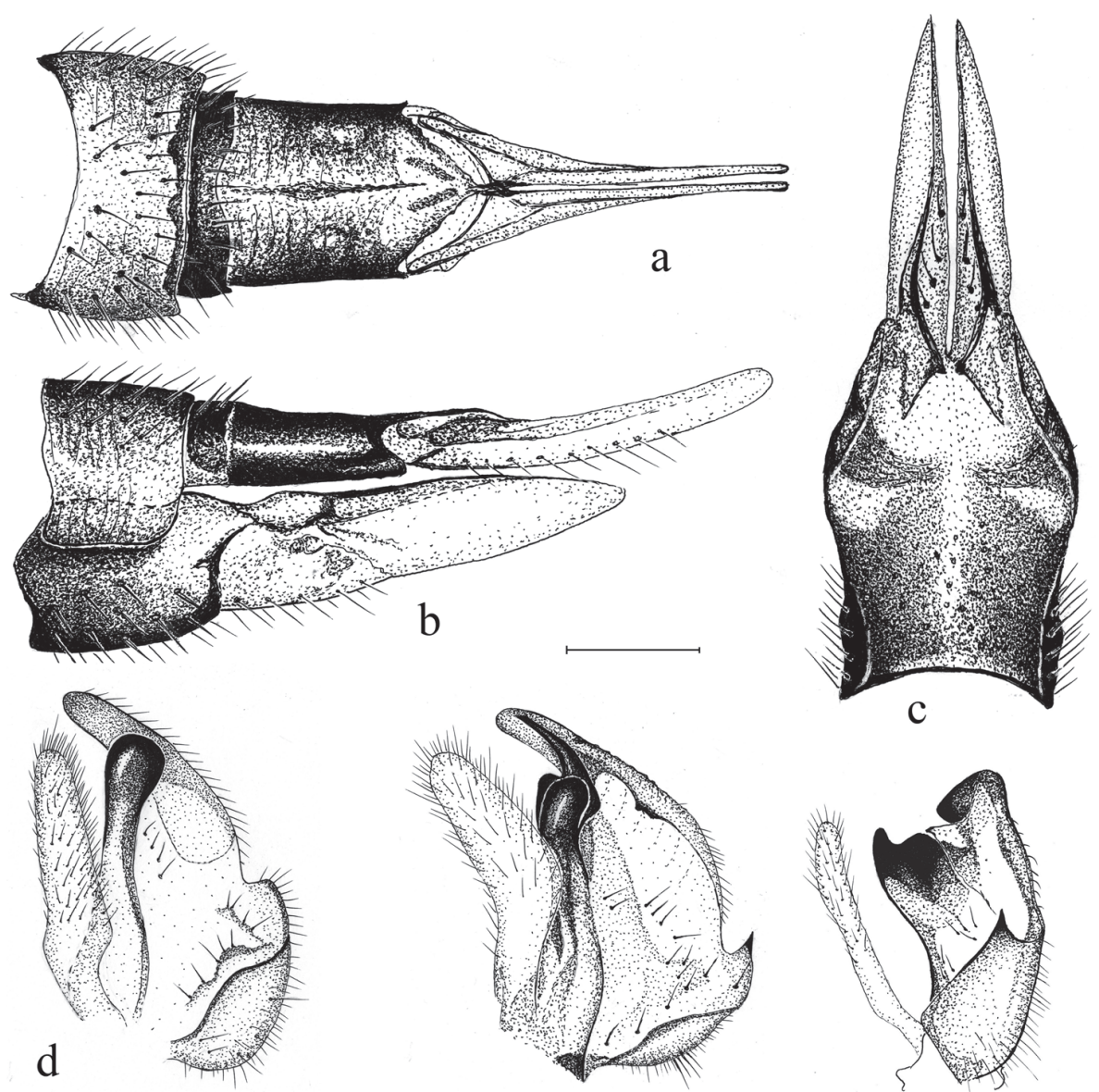

$\mathrm{C}$
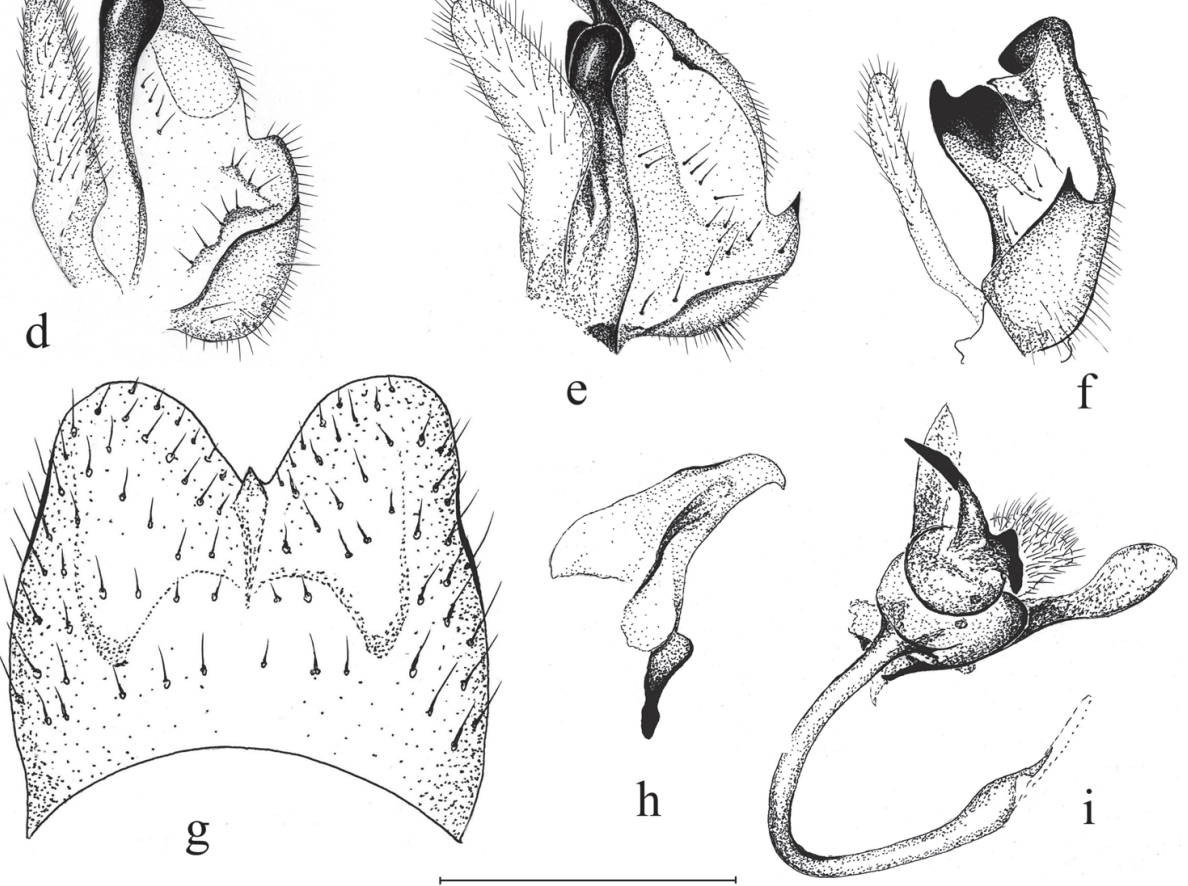

Figure 4. Tipula (Pterelachisus) recondita Pilipenko \& Salmela sp. n., paratype female (Russia) a-c $T$. ( $P$.) pauli Mannheims $\mathbf{d}$ and $T$. ( $P$.) imitator Alexander $(\mathbf{e}, \mathbf{f}, \mathbf{g}, \mathbf{h}, \mathbf{i})$. a female terminal abdominal segments and cerci, dorsal view $\mathbf{b}$ female terminal abdominal segments, cerci and hypovalva, lateral view c female hypovalva and $8^{\text {th }}$ sternite, dorsal view $\mathbf{d}-\mathbf{e}$ male inner gonostylus, lateral view $\mathbf{f}$ outer and inner gonostylus, posterior view $\mathbf{g} 9^{\text {th }}$ tergite, dorsal view $\mathbf{h}$ aedeagal guide, lateral view $\mathbf{i}$ sperm pump and aedeagus, ventro-lateral view. Scale bars: $0.5 \mathrm{~mm}$. 
and a small but discernible tooth in the midpoint; the lower beak of inner gonostylus is roundish and black, but the outer basal lobe bears no stout, black spines (Fig. 4d). Tipula (P.) imitator is known from Japan and Kuril Islands and T. (P.) pauli from Europe, Altay and Russian Far East (Oosterbroek 2012, V. Pilipenko pers. obs.).

Based on COI divergence, the new species is apparently rather isolated from the members of the subgenus Pterelachisus (Fig. 1). Among the other species vs. the new species, interspecific distances varied from $5.3 \%$ (Tipula winthemi Lackschewitz) to $16.1 \%$ (Tipula laetibasis Alexander). Mean of the minimum interspecific distances was $8.8 \%$. According to K2P divergence, the new species is closest to T. winthemi (5.3\%), T. jutlandica Nielsen (5.5\%), T. stenostyla Savchenko (6.6\%) and T. pauli (6.8\%); distances between the other species range from 7.4 to $16.1 \%$. In other words, no very close relatives were present in the pair-wise comparisons of COI sequences. For example, much shorter interspecific K2P distances were found between T. varipennis/T. pseudovariipennis (1.5\%), T. mutilal T. wablgreni $(2.2 \%)$, T. stenostylal T. winthemi (3.7 \%). However, it must be emphasized that T. imitator was not included in COI analysis, due to the lack of fresh material. Given to the morphological similarity of the new species and T. imitator, it is likely that their barcoding distances would be similar to those three comparisons given above.

There are some morphological differences ( $9^{\text {th }}$ tergite, inner gonostylus) between Finnish and Russian specimens, perhaps due to the long distance and lack of gene flow between the populations. These differences, however, are here considered to be intraspecific variation. Very small K2P divergence of COI gene ( $0.2 \%)$ between Finnish and Russian specimens also substantiates the presence of one widespread, but disjunct, species. In rare cases (see Burns et al. 2007) differences of only one to three nucleotides may be observed between otherwise (for example morphologically and ecologically) distinct species. However, in this case we were able to produce $524 \mathrm{bp}$ of high quality sequence, instead of $<400$ as in the problematic cases of Burns et al. (2007). Moreover, the known biologies of the Finnish and Russian individuals seem alike. To say more of the COI variation, it would be essential to collect more individuals which is rather difficult, given the rarity of the species.

The new species is most probably a very rare tipulid. Despite the rather long tradition of crane fly taxonomy and faunistics in North Europe, this species has hitherto remained unnoticed. One of the authors (JS) has within 12 years identified some 70 000 crane flies from a Finnish Malaise trapping material consisting of 476 sampling sites and ca. 1670 Malaise trapping months. Thus, despite this relatively large sampling effort, only three specimens from a single locality have been caught. The true range of the species is Palaearctic, whether disjunct or not remains to be seen. In Northwestern Europe the species is likely to occur in the north boreal zone (for further information on boreal ecoregions or vegetation zones, see e.g. Ahti et al. 1968). Tipula (P.) recondita Pilipenko \& Salmela, sp. n. may be confined to old-growth forests, and its rarity is perhaps due to the narrow habitat niche. On the other hand, the new species may be hard to collect using traditional methods. Larval associations of this species are unknown, but some T. (Pterelachisus) species are saproxylic, i.e. dependent on decaying trees. Such species are e.g. T. (P.) pseudoirrorata Goetghebuer and T. (P.) stenostyla Savchenko (Salmela 2009), both of them also encountered in the type locality. 
To our regret we were not able to examine the holotype male of $T$. imitator (D. Furth, pers. comm.). Description of that species was based on a single male specimen (Alexander 1953). We have however examined other material (two male specimens, see above) that very likely represents $T$. imitator. Despite morphological similarity of $T$. (P.) recondita Pilipenko \& Salmela, sp. n. and T. imitator, we are confident that these are separate taxa, due to the differences in the structure of male hypopygium.

\section{Acknowledgements}

Special thanks to Pjotr Oosterbroek (Amsterdam) for his help with the vast Tipula (Pterelachisus) literature. It would have been much more laborious for us to resolve the status of the new species without Pjotr's help. Metsähallitus, Lapin luontopalvelut (Finnish Natural Heritage Services) provided a permission to collect insects in Iso Mustavaara Nature Reserve. Comments by John Kramer (Leicester), Fenja Brodo (Ottawa), anonymous referee and Vladimir Blagoderov (London) improved manuscript. Aleksanteri Hihnavaara (Ponku) is thanked for such a cheerful field company. Barcode sequences were obtained at the Canadian Centre for DNA Barcoding based in the Biodiversity Institute of Ontario at the University of Guelph. Their work was supported by funding from the Government of Canada through Genome Canada and the Ontario Genomics Institute in support of the International Barcode of Life Project. Finnish Barcode of Life (FinBOL) is also thanked for a help in the barcoding process. JS was financially supported by Finnish Cultural Foundation, Oskar Öflunds Stiftelse and Societas pro Fauna et Flora Fennica and EJV by Betty Väänäsen Rahasto.

\section{References}

Ahti T, Hämet-Ahti L, Jalas J (1968) Vegetation zones and their sections in northwestern Europe. Annales Botanici Fennici 5: 169-211.

Alexander CP (1919) The crane-flies of New York. Part I. Distribution and taxonomy of the adult flies. Memoirs, Cornell University Agricultural Experiment Station 25: 767-993.

Alexander CP (1935) New or little-known Tipulidae from eastern Asia (Diptera). XXIV. Philippine Journal of Science 56: 525-562.

Alexander CP (1953) Records and descriptions of Japanese Tipulidae (Diptera). Part I. The crane-flies of Shikoku. I. Philippine Journal of Science 82: 21-75.

Alexander CP (1965) New subgenera and species of crane-flies from California (Diptera: Tipulidae). Pacific Insects 7: 333-386.

Alexander CP, Byers GW (1981) Tipulidae 7. In: McAlpine JF, Peterson BV, Shewell GE, Teskey HJ, Vockeroth JR, Wood DM (Eds) Manual of Nearctic Diptera 1. Monograph No. 27, Biosystematic Research Institute, Ottawa, Ontario, 153-190. http://www.esc-sec. ca/aafcmonographs/manual_of_nearctic_diptera_vol_1.pdf 
Aljanabi S, Martinez I (1997) Universal and rapid salt-extraction of high quality genomic DNA for PCR- based techniques. Nucleic Acids Research 25: 4692-4693. doi: 10.1093/nar/25.22.4692 Burns JM, Janzen DH, Hajibabaei M, Hallwachs W, Hebert PDN (2007) DNA barcodes of closely related (but morphologically and ecologically distinct) species of skipper butterflies (Hesperiidae) can differ by only one to three nucleotides. Journal of the Lepidopterists' Society 63:138-153.

Folmer O, Black M, Hoeh W, Lutz R, Vrijenhoek R (1994) DNA primers for amplification of mitochondrial cytochrome c oxidase subunit I from diverse metazoan invertebrates. Molecular Marine Biology and Biotechnology 3: 294-299.

Frommer SI (1963) Gross morphological studies of the reproductive system in representative North American crane flies (Diptera: Tipulidae). Kansas University Science Bulletin 44: 535-625.

Gatesy J. DeSalle R, Wahlberg N (2007) How Many Genes Should a Systematist Sample? Conflicting Insights from a Phylogenomic Matrix Characterized by Replicated Incongruence. Systematic Biology 56: 355-363. doi: 10.1080/10635150701294733

Gilbert MTP, Moore W, Melchior L, Worobey M (2007) DNA Extraction from Dry Museum Beetles without Conferring External Morphological Damage. PLoS ONE 2: e272. doi: 10.1371/journal.pone.0000272

Hausmann A, Haszprunar G, Hebert PDN (2011) DNA Barcoding the Geometrid Fauna of Bavaria (Lepidoptera): Success, Surprises, and Questions. PLoS ONE 6: e17134. doi: 10.137/journal.pone.0017134

Huemer P, Hebert PDN (2011) Cryptic diversity and phylogeography of high alpine Sattleria - a case study combining DNA barcodes and morphology (Lepidoptera: Gelechiidae). Zootaxa 2981: 1-22.

Kimura M (1980) A simple method for estimating evolutionary rate of base substitutions through comparative studies of nucleotide sequences. Journal of Molecular Evolution 16: 111-120. doi: 10.1007/BF01731581

Meier R (2008) DNA Sequences in Taxonomy: Opportunities and Challenges. In Wheeler QD (Ed), The New Taxonomy. Systematics Association Special Volume, CRC Press, 95-128.

Memon N, Meier R, Mannan A, Su Feng-Yi K (2006) On the use of DNA sequences for determining the species limits of a polymorphic new species in the stink bug genus Halys (Heteroptera: Pentatomidae) from Pakistan. Systematic Entomology 31: 703-710. doi: 10.1111/j.1365-3113.2006.00350.x

Oosterbroek P (2011) Catalogue of the Craneflies of the World (Diptera, Tipuloidea: Pediciidae, Limoniidae, Cylindrotomidae, Tipulidae) http://nlbif.eti.uva.nl/ccw/index.php

Park D-S, Foottit R, Maw E, Hebert PDN (2011) Barcoding Bugs: DNA-Based Identification of the True Bugs (Insecta: Hemiptera: Heteroptera). PLoS ONE 6(4): e18749. doi: 10.1371/journal.pone.0018749

Pilipenko VE (2009) A check list of craneflies (Diptera, Tipulidae) of the Central European territory of Russia. Zoosymposia 3: 203-220.

Ratnasingham S, Hebert PDN (2007) BOLD: The Barcode of Life Data System (www. barcodinglife.org). Molecular Ecology Notes 7: 355-364. doi: 10.1111/j.14718286.2006.01678.x 
Salmela J (2009) The subgenus Tipula (Pterelachisus) in Finland (Diptera, Tipulidae) - species and biogeographic analysis. Zoosymposia 3: 255-271.

Salmela J (2010) Cranefly (Diptera, Tipuloidea \& Ptychopteridae) fauna of Limhamn limestone quarry (Sweden, Malmo). Diversity and faunistics viewed from a NW European perspective. Norwegian Journal of Entomology 57: 123-135.

Salmela J (2011) Annotated list of Finnish crane flies (Diptera: Limoniidae, Tipulidae, Pediciidae \& Cylindrotomidae). Entomologica Fennica 22: 219-242.

Salmela J, Autio O (2007) Redescription of Tipula octomaculata Savchenko, with notes on related Holarctic species (Diptera, Tipulidae). Zootaxa 1527: 53-58.

Savchenko EN (1964) Crane-flies (Diptera, Tipulidae), Subfam. Tipulinae, Genus Tipula L., 2. Fauna USSR, N.S. 89, Nasekomye Dvukrylye [Diptera], 2(4): 1-503 [in Russian].

Schlick-Steiner BC, Steiner FM, Seifert B, Stauffer C, Christian E, Crozier RH (2010) Integrative taxonomy: a multisource approach to exploring biodiversity. Annual Review of Entomology 55: 421-438. doi: 10.1146/annurev-ento-112408-085432

Skevington JH, Kehlmaier C, Ståhls G (2007) DNA Barcoding: Mixed results for big-headed flies (Diptera: Pipunculidae). Zootaxa 1423: 1-26.

Smith MA, Woodley NE, Janzen DH, Hallwachs W, Hebert PDN (2006) DNA barcodes reveal cryptic hostspecificity within the presumed polyphagous members of a genus of parasitoid flies (Diptera: Tachinidae). Proceedings of the National Academy of Sciences of the United States of America 103: 3657-3662. doi: 10.1073/pnas.0511318103

Tamura K, Peterson D, Peterson N, Stecher G, Nei M, Kumar S (2011) MEGA5: Molecular Evolutionary Genetics Analysis using Maximum Likelihood, Evolutionary Distance, and Maximum Parsimony Methods. Molecular Biology and Evolution 28: 2731-2739. doi: $10.1093 / \mathrm{molbev} / \mathrm{msr} 121$

Taylor HR, Harris WE (2012) Am emergent science on the brink of irrelevance: a review of the past 8 years of DNA barcoding. Molecular Ecology Resources. doi: 10.1111/j.17550998.2012.03119.x

Theowald B (1980) 15. Tipulidae. In: Lindner E. (Ed.), Die Fliegen der palaearktischen Region, 3(5)1, Lief. 324: 437-538.

Ujvárosi L, Bálint M, Meszaros N, Popescu O (2009) Genetic diversity with morphological imprints among Pedicia (Amalopis) occulta (Meigen, 1830) (Diptera, Pediciidae) populations in the Carpathian area: Preliminary results. Lauterbornia 68: 47-58.

Ujvárosi L, Bálint M (2012) Discovery of the second European Amalopis species: an integrative survey of the widespread Pedicia (Amalopis) occulta (Meigen, 1830) (Insecta, Diptera, Pediciidae). Zootaxa 3189: 1-28.

deWaard JR, Ivanova NV, Hajibabaei M, Hebert PDN (2008) Assembling DNA Barcodes: Analytical Protocols. In: Martin C (Ed) Methods in Molecular Biology: Environmental Genetics; Humana Press Inc., Totowa, USA, 275-293.

Ward RD, Zemlak TS, Innes BH, Last PR, Hebert PDN (2006) DNA barcoding Australia’s fish species. Philosophical Transactions of the Royal Society B 360: 1847-1857. doi: 10.1098/rstb.2005.1716 